Chirurgia (2017) 112: 436-442

No. 4, July - August

Copyright@ Celsius

http://dx.doi.org/10.21614/chirurgia.112.4.436

\title{
Does the Surgical Management of the Intercostobrachial Nerve Influence the Postoperatory Paresthesia of the Upper Limb and Life Quality in Breast Cancer Patients?
}

\author{
Hankó-Bauer Orsolya', Marius Florin Coros', Simona Stolnicu ${ }^{2}$, Adrian Naznean ${ }^{3}$, Rares Georgescu' ${ }^{1}$ \\ 'Univeristy of Medicine and Pharmacy Targu Mures, Department of Surgery \\ ${ }^{2}$ Univeristy of Medicine and Pharmacy Targu Mures, Department of Pathology \\ ${ }^{3}$ Univeristy of Medicine and Pharmacy Targu Mures, Department of Foreign languages
}

Corresponding author: Marius Florin Coros, MD Adress: Gheorghe Marinescu no 1, Targu Mures, Romania E-mail:mcoros@gmail.com
Received: 02.04.2017 Accepted: 10.05 .2017

\section{Rezumat}

Influenta managementului nervului intercostobrahial asupra paresteziei postoperatorii a membrului superior și a calității vieții pacientilor cu cancer mamar

Scopul studiului: este evaluarea durerii şi a paresteziei postoperatorii secundare secționării nervului intercostobrahial (NICB), respectiv de a determina influența acesteia asupra calitatății vieții pacienților operați pentru cancer mamar.

Material şi metodă: Studiul retrospectiv nerandomizat include 100 de pacienți limfadenectomizați pentru cancer mamar. Folosind un chestionar am studiat calitatea vieții pacienților în perioada postoperatorie. Pentru analiza statistică am folosit programul GraphPad Prism, testul Fisher şi Chi pătrat.

Rezultate: Au fost incluşi în studiu 100 de pacienți cu vârsta medie de 59,7 ani. În 50 de cazuri NICB a fost prezervat (grup 1), iar în celelate 50 de cazuri a fost secționat în timpul intervenției chirurgicale (grup 2). Din 100 de cazuri 46 au dezvoltat parestezie postoperatorie, din care $29(63,1 \%)$ din grupul 2 şi $17(36,9 \%)$ din grupul 1. S-au identificat 21 de cazuri fără parestezie postoperatorie la care NICB a fost secționat. Din grupul 2 semnificativ mai mulți pacienți au dezvoltat parestezie postoperatorie decât din grupul 1 $(p=0,026, R R=0,58, C I=0,3728-0,9218)$. In cazuistica prelucrată nu am găsit diferențe semnificative între cele două grupuri de pacienți în ceea ce priveşte activitatea zilică, $(p=0,2)$, sleeping cycle $(p=0,2)$, sau calitatea vieții în general $(p=0,67)$.

Conluzii: Managementul chirurgical a NICB are o influență majoră 
în dezvoltarea paresteziei postoperatorii. Deşi parestezia nu are un efect negativ asupra calității vieții pacienților, în opinia noatră este importantă salvarea NICB pentru a preveni parestezia postoperatorie.

Cuvinte cheie: nervul intercostobrahial, chirurgie axilară, parestezie, cancer mamar

\begin{abstract}
The aim of our study was to evaluate the extent to which the preservation or the section of the intercostobrachial nerve (ICBN) influences the development of postoperatoryparesthesia and to assess whether the development of paresthesiamay change the patient's life quality after surgical treatment for breast carcinoma.

Material and methods: We performed a nonrandomized retrospective study including 100 patients who underwent axillary lymph node dissection for infiltrating breast carcinoma associated with axillary lymph node metastases. Using a questionnaire we studied the patients' general life quality in the postoperative period. For the statistical analysis we used GraphPad Prism, Fisher's exact test and Chi square test.

Results: 100 patients were included in our study with a mean age of 59.7 years. In 50 cases, the ICBN was preserved (Group 1), while in the remaining 50 cases the ICBN was sectioned during surgery (Group 2). Significantly more patients from Group 2 complained about postoperative paresthesia $(p=0.026)$. In our series, the management of the ICBN cannot be significantly correlated with the impairment of the patients' daily activities $(p=0.2)$, sleeping cycle $(p=0.2)$, and general life quality after surgery $(\mathrm{p}=0.67)$.

We can conclude that the management of ICBN has a great influence on the development of postoperative paresthesia. Although the paresthesia does not have a negative effect on the patient's life quality in the postoperative period, in our opinion it is important to preserve the ICBN in order to prevent postoperative paresthesia.
\end{abstract}

Key words: intercostobrahial nerve, axillary surgery, paresthesia, breast cancer

\section{Background}

The intercostobrachial nerve (ICBN) is the lateral cutaneous branch of the second intercostal nerve, which enters the axilla by perforating the second intercostal space and the serratus anterior in the midaxillary line. It then runs obliquely towards the posteromedial border of the upper arm presenting a significant variability which means that the intercostobrachial nerve is at high risk of being damaged during axillary surgery. As part of the somatic nervous system, it provides specific sensory information regarding the skin, and its damage may be the cause of persistent pain and sensory disturbances of the skin that covers the axilla and the medial side of the arm (1-4).

Patients treated with axillary lymph node dissection for breast carcinoma often complain about persistent pain, sensory loss, and numbness of the upper arm. Even though the topic is still under debate among surgeons, the surgical management of the intercostobrachial nerve may have an important role in the pathophysiology of these complaints. The above-mentioned anatomical description of the intercostobrachial nerve shows that the location of the nerve implies high vulnerability during axillary surgery. Management of the intercostobrachial nerve is controversial during this surgical 
procedure, and it is often sacrificed because of the technical difficulties of preserving it. Although the value of preserving the nerve has been claimed, no randomized studies have been conducted to compare the sacrifice of this nerve with its preservation (5-10).

The aim of our study was to evaluate to what extent the preservation or the sectioning of the ICBN during surgery may influence the development of postsurgical paresthesia and pain in patients with breast carcinoma. Our secondary aim was to assess whether these complications may change the breast cancer patient's life quality in the postoperative period.

\section{Material and Methods}

We performed a nonrandomised retrospective study including patients diagnosed with breast carcinoma who underwent quadranectomy and/or mastectomy with axillary dissection between 2013-2015. The management of the ICBN was established during the surgery. If the ICBN was surrounded by a conglomerate of lymph nodes or tightly adherent to enlarged or suspicious lymph nodes, we considered that it should be sectioned in order not to compromise the radicality of the procedure. The preservation of the ICBN never affected the radicality of the surgical procedure.

We telephonically contacted these patients, who filled in a questionnaire drafted by our department regarding the appearance of upper limb paresthesia and pain in the postoperative period and the location of the paresthesia (Table 1). Also, since postoperative paresthesia can seriously influence the patient's life in both physical and mental ways, we wanted to assess how serious the impact on the patient's life is, how they can manage their daily routine, and how much their living standards are influenced. In order to gather information, we included the above questions in the questionnaire inquiring about their daily activities and their living standards in the postoperative period.

The results of the questionnaire were collected in a database (Microsoft Excel 2010); for data processing we used GraphPad Prism version 6.01 for Windows, Fisher test, and Chi square test. The results were considered statistically significant if $\mathrm{p}<0.05$.

\section{Results}

One hundred patients were included in our study with a mean age of 59.7 years (31- 80), of which 88 were women and 2 patients were

Table 1. Questionnaire regarding the appearance of upper limb paresthesia in the postoperative period after surgical treatment for breast carcinoma

\begin{tabular}{ll}
\hline Question & Answer \\
\hline 1. Did you experience paresthesia in the postoperative period? & 0 Yes \\
\hline 2. Did you experience pain in the postoperative period? & 0 Yes \\
\hline 3. In what location did the paresthesia appear? & 0 No Axillary \\
& 0 Elbow \\
& 0 Wrist \\
4. How much does the paresthesia influence the daily routine? & 0 Other \\
& 0 Increasingly \\
& 0 Moderately \\
5. How much does the paresthesia influence your general living standards? & 0 Slightly \\
& 0 Without influence \\
& 0 Increasingly \\
6. Do you have any sleeping disorders because of the paresthesia? & 0 Moderately \\
\hline
\end{tabular}


male. In 50 cases, the ICBN was preserved (Group 1), and in the remaining 50 cases the ICBN was sectioned during surgery (Group 2). None of these patients experienced upper limb pain in the postoperative period. In $46(46 \%)$ cases, the patients developed postoperative paresthesia, of which 29 patients $(63.1 \%)$ had sectioned ICBN and 17 cases preserved, undamaged ICBN (36.9\%). However, we found 21 cases with sectioned ICBN but without postoperative paresthesia.

Significantly more patients complained about postoperative paresthesia, patients in whom the ICBN had been sectioned, Group $2(\mathrm{p}=0.026$, $\mathrm{RR}=0.58, \mathrm{CI}=0.3728$ - 0.9218) (Fig. 1).

\section{Localization of Paresthesia}

Of the 46 patients with paresthesia, 9 patients (19.56\%) complained about localized axillary paresthesia ( 8 cases from Group 1, and 1 case from Group 2), 25 patients (44.64\%) had paresthesia in the upper arm (5 cases Group 1, and in 20 cases from Group 2) and 12 patients (26.08\%) described forearm paresthesia (4 cases from Group 1, and 8 cases from Group 2). In this series, there was a significant relationship between the localization of the paresthesia and the management of the intercostobrachial nerve: the upper and forearm paresthesia is statistically significant with respect to the sectioned ICBN (p=0.0011) (Fig. 2).

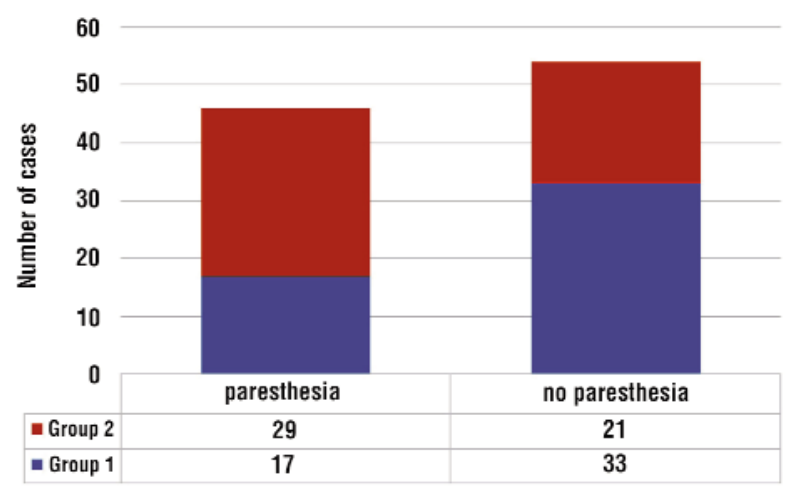

Figure 1. Correlation between the management of the intercostobrachial nerve and the appearance of postoperative paresthesia
Impairment of Daily Activity, Sleep Cycle, and Life Quality

In our series, 33 patients $(71.7 \%)$ declared that postoperative paresthesia influenced their daily activities, 21 patients (63.63\%) mentioned slight influence, 8 patients (24.24\%) moderate influence, 4 patients (12.12\%) increased influence; 11 patients (23.9\%) had sleeping disorders due to the paresthesia, and 33 patients $(71.7 \%)$ com $^{-}$ plained about the impairment of general life quality $(75.75 \%$ with slight impairement, $21.21 \%$ with moderate impairment, $3.03 \%$ with increased impairment) (Figs. 3, 4, 5).

In our series, the management of the ICBN cannot be significantly correlated with the impairment of the patients' daily activities $(p=0.2)$, sleep cycle $(p=0.2)$, and general life quality after surgery $(\mathrm{p}=0.67)$.

\section{Intercostobrachial Nerve Management and Radicality}

Also, in this series, the mean number of the excised lymph nodes during axillary surgery was 17.5 . There was no statistically significant correlation between the management of the ICBN and the number of excised lymph nodes $(\mathrm{p}=1 ; \mathrm{OR}=0.94)$ (Fig. 6).

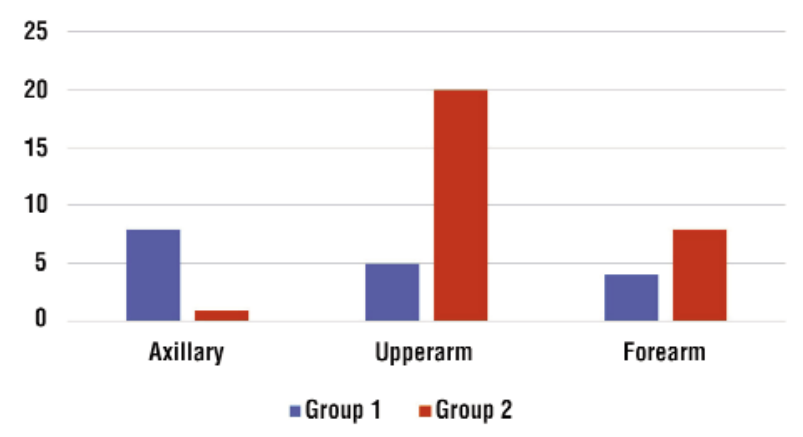

Figure 2. Localization of the paresthesia according to the management of the intercostobrachial nerve 


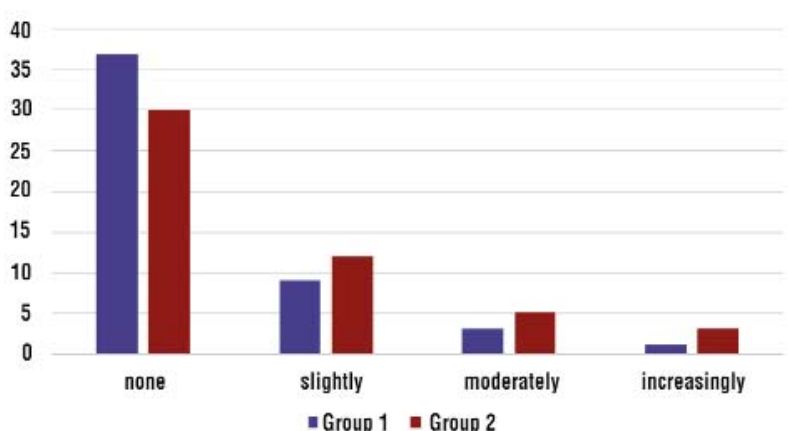

Figure 3. The influence of postoperative paresthesia on patients' daily activities

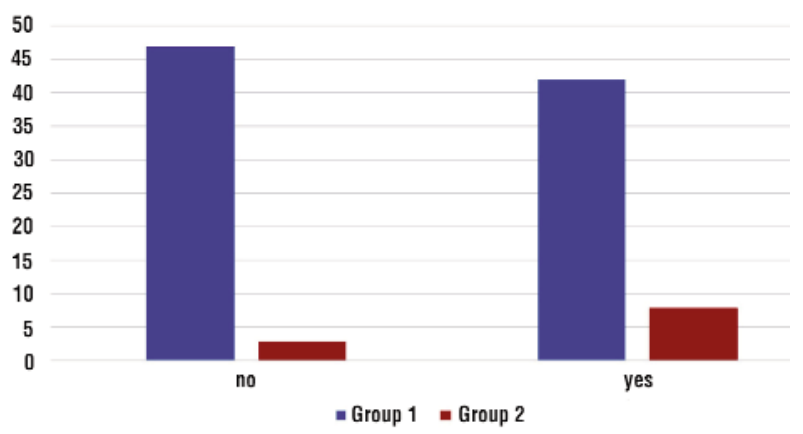

Figure 5. Influence of paresthesia on dormancy

\section{Discussions}

The most important prognostic parameter in breast carcinoma is the status of the axilla, the presence of the lymph node metastases being associated with a worse prognosis (20). Considering the anatomic position of the ICBN, its management is controversial during the surgical treatment. Some authors state that there may be a connection between the dissection of the nerve and the appearance of the persistent pain and/or sensory disturbance.

In our study, the ICBN was saved in 50 cases, and it was sectioned during the surgery in the other 50 cases. In $46(46 \%)$ of all the 100 cases, the patients developed postoperative paresthesia, of which 29 patients (63.1\%) had sectioned ICBN and 17 cases preserved, undamaged ICBN (36.9\%). Significantly more patients complained about postoperative paresthesia in which the ICBN was sectioned,

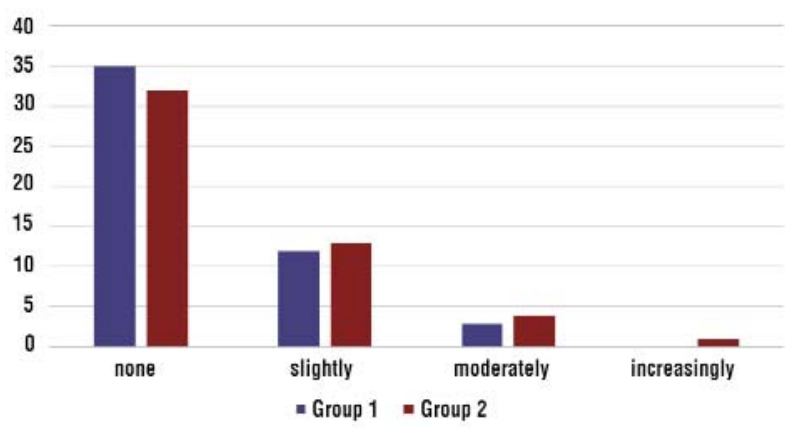

Figure 4. Influence of paresthesia on patients' general life quality

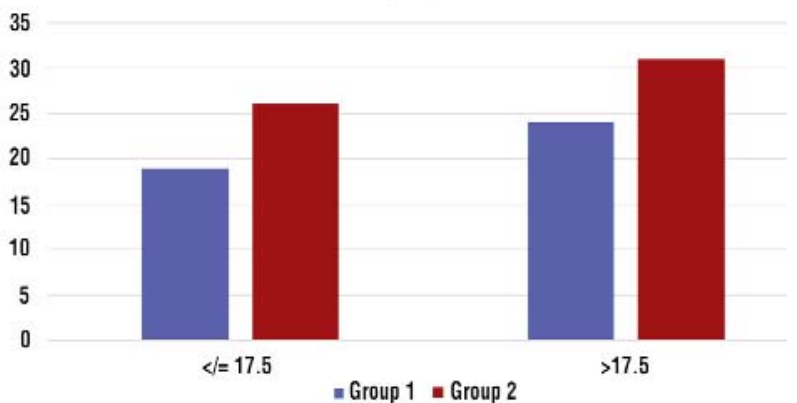

Figure 6. The influence of the ICBN management on the number of excised lymph nodes during axillary surgery

Group 2 and we found significant correlation between the surgical management of the ICBN and the appearance of persistent paresthesia. In our series, none of the patients $(0 \%)$ complained about postoperative pain.

Similar to our results, previous studies found significant correlation between ICBN damage and sensory disturbance following the surgery (13-16).

A meta-analysis and systematic literature review published by Warren et al. in 2014 concluded that sectioning the ICBN during axillary surgery is strongly associated with a high risk of sensory disturbance, more likely hyposensitivity (11).

K.G. Andersen et al. recently published a prospective study in which they concluded that the type of the ICBN handling (preservation, partial preservation, or sectioning) during axillary lymph node dissection does not influence the appearance of acute postoperative pain in the 
Table 2. Summarized results of the questionnaire; patients' daily routine, dormancy, and general life quality after surgery according to the management of the intercostobrachial nerve. (OR-Odds Ratio, ICBN-intercostobrachial nerve)

\begin{tabular}{lccccc}
\hline & $\begin{array}{c}\text { Number of } \\
\text { patients }\end{array}$ & $\begin{array}{c}\text { Number of } \\
\text { patients with } \\
\text { saved ICBN }\end{array}$ & $\begin{array}{c}\text { Number of } \\
\text { patients with } \\
\text { sectioned ICBN }\end{array}$ & p & OR \\
\hline Influenced daily routine & 33 & 13 & 20 & 0.2 & 1.8974 \\
\hline No influence on daily routine & 67 & 37 & 30 & 0.2 & 0.375 \\
\hline Sleeping disorders & 50 & 42 & 8 & 3 & 0.67 \\
\hline No sleeping disorders & 50 & 42 & 15 & 32 & 0.761 \\
\hline Influenced general life quality & 33 & 35 & 32 & \\
\hline No influence on general life quality & 67 & & 18 & \\
\hline
\end{tabular}

(OR: Odds Ratio)

first week after the surgery, similar to our results (12).

A study published in 2014 by Taira et al. prospectively analyzed the association between ICBN preservation, the sensory change, and health related life quality, and concluded that it had a benefit on long term hypoesthesia, but no improvement of postoperative pain or health related life quality had been noticed (3).

A questionnaire was drafted by our department including not only the development of pain and upper limb paresthesia and the location of the paresthesia, but also the impact on the patient's life, how they can manage their daily routine, and how much their living standards are influenced. We included the above parameters into a questionnaire inquiring about their daily activities and their living standards in the postoperative period. To the best of our knowledge, no other similar questionnaires have been implemented in breast surgery units in order to gather this information.

Taking into consideration the influence of the postoperative paresthesia on daily routine, on general living standards, and on dormancy we found no significant relation between patients' life quality and the ICBN management, similar results to other previously published studies $(17,18,19)$.

According to ICBN preservation reliability, a study published in 2014 by Zheng et al. concluded after a histological observational study that unless large lymphatic nodes adhere to the ICBN, its preservation is feasible from oncological point of view (20).

\section{Conclusions}

We can conclude that the ICBN in our series had a great influence on the development of postoperative paresthesia, in most of the cases localized in the upper arm (especially in patients of the Group 2). However, none of the patients with sectioned ICBN complained of pain. Although it does not have a negative effect on the patient's life quality in the postoperative period, we consider that preservation of ICBN is important in order to prevent postoperative paresthesia.

\section{References}

1. Macea JR, Fregnani JHTG. Anatomy of the thoracic wall, axilla and breast. Int. J. Morphol. 2006;24(4):691-704.

2. Loukas M, Grabska J, Tubbs RS, Louis RG Jr. An unusual union of the intercostobrachial nerve and the medial pectoral nerve. Folia Morphol (Warsz). 2007;66(4):356-9.

3. Taira N, Shimozuma K, Ohsumi S, Kuroi K, Shiroiwa T, Watanabe T, et al. Impact of preservation of the intercostobrachial nerve during axillary dissection on sensory change and health-related quality of life 2 years after breast cancer surgery. Breast Cancer. 2014;21(2):18390. doi: 10.1007/s12282-012-0374-x. Epub 2012 Aug 30.

4. Hwang K, Huan F, Hwang SW, Kim SH, Han SH. The course of the intercostobrachial nerve in the axillary region and as it is related to transaxillary breast augmentation. Ann Plast Surg. 2014;72(3): 337-9. doi: 10.1097/SAP.0b013e31825c07ba.

5. Wijayasinghe N1, Andersen KG, Kehlet H. Neuronal blockade for persistent pain after breast surgery. Reg Anesth Pain Med. 2014; 39(4):272-8. doi: 10.1097/AAP.0000000000000101.

6. Vitug AF, Newman LA. Complications in breast surgery. Surg Clin North Am. 2007;87(2):431-51, x. 
7. Paredes JP, Puente JL, Potel J. Variation in sensitivity after sectioning the intercostobrachial nerve. Am J Surg. 1990;160(5): 525-8.

8. Wallace AM, Wallace MS. Postmastectomy and postthoracotomy pain. Anesthesiology Clinics of North America. 1997;15(2):353-70.

9. Klingelhöfer J, Conrad B. Lesion of the intercostobrachial nerve. Nervenarzt. 1985 Aug;56(8):449-52. German

10. Haroutiunian S, Nikolajsen L, Finnerup NB, Jensen TS. The neuropathic component in persistent postsurgical pain: a systematic literature review. Pain. 2013;154(1):95-102. doi: 10.1016/j.pain. 2012.09.010

11. Warrier S, Hwang S, Koh CE, Shepherd H, Mak C, Carmalt H, et al Preservation or division of the intercostobrachial nerve in axillary dissection for breast cancer: meta-analysis of randomised controlled trials. Breast. 2014;23(4):310-6. doi: 10.1016/j.breast. 2014.01.014. Epub 2014 Feb 24

12. Andersen KG, Aasvang EK, Kroman N, Kehlet H. Intercostobrachia nerve handling and pain after axillary lymph node dissection for breast cancer. Acta Anaesthesiol Scand. 2014;58(10):1240-8. doi: 10.1111/aas.12393

13. Abdullah TI, Iddon J, Barr L, Baildam AD, Bundred NJ. Prospective randomized controlled trial of preservation of the intercostobrachial nerve during axillary node clearance for breast cancer. $\mathrm{Br}$ J Surg. 1998;85(10):1443-5.

14. Temple WJ, Ketcham AS. Preservation of the intercostobrachial nerve during axillary dissection for breast cancer. Am J Surg. 1985;
150(5):585-8

15. Salmon RJ, Ansquer $Y$, Asselain B. Preservation versus section of intercostal-brachial nerve (IBN) in axillary dissection for breast cancer--a prospective randomized trial. Eur J Surg Oncol. 1998; 24(3):158-61.

16. Freeman SR, Washington SJ, Pritchard T, Barr L, Baildam AD, Bundred NJ. Long term results of a randomized prospective study of preservation of the intercostobrachial nerve. Eur J Surg Oncol. 2003;29(3):213-5.

17. Peintinger F, Reitsamer R, Stranzl H, Ralph G. Comparison of quality of life and arm complaints after axillary lymph node dissection vs sentinel lymph node biopsy in breast cancer patients. $\mathrm{Br} \mathrm{J}$ Cancer. 2003;89(4):648-52.

18. Engel J, Kerr J, Schlesinger-Raab A, Sauer H, Hölzel D. Axilla surgery severely affects quality of life: results of a 5-year prospective study in breast cancer patients. Breast Cancer Res Treat. 2003; 79(1):47-57.

19. Aerts PD, De Vries J, Van der Steeg AF, Roukema JA. RoukemaThe relationship between morbidity after axillary surgery and longterm quality of life in breast cancer patients: the role of anxiety. Eur Surg Oncol. 2011;37(4):344-9. doi: 10.1016/i.ejso.2011.01.016.

20. Zheng H, Shi C, Zhang S, Tang Z, Chen Y, Ding M, et al. Histological observation of preserving intercostobrachial nerve during axillary lymph node dissection for breast carcinoma. Zhonghua Yi Xue Za Zhi. 2014;94(46):3646-8. Chinese 